\title{
Nitrogen and Phosphorus Dynamics in the Shallow Lake Agmon (Hula Valley, Israel)
}

\author{
Moshe Gophen \\ Migal-Scientific Institute in Galilee, Kiryat Shmone, Israel \\ Email: gophen@migal.org.il
}

Received 12 February 2015; accepted 1 March 2015; published 5 March 2015

Copyright (C) 2015 by author and Scientific Research Publishing Inc.

This work is licensed under the Creative Commons Attribution International License (CC BY). http://creativecommons.org/licenses/by/4.0/

(c) (i) Open Access

\begin{abstract}
Lake Agmon is a newly created shallow body of water which is a principle component of a reclamation project (Hula Project, HP) in the Hula Valley (Israel). The objectives of the HP are aimed at Lake Kinneret water quality protection, and improvements of the hydrological, and agricultural managements within the entire Hula Valley including the eco-touristic quality of the Agmon site. Thirteen years of research and monitoring, are summarized by focusing on nitrogen and phosphorus dynamics. It was found that the decay of submerged vegetation was the major $P$ contribution to the Agmon effluents as dissolved (TDP) and plant debris particle forms. Peat soil gypsum dissolution contribute sulfate to drained waters and consequently to Agmon outflows. The Agmon system is operated as a nitrogen sink by de-nitrification and particulate sedimentation and contributor of plant mediated phosphorus. In the reconstructed Jordan flows into the Agmon, a stable composition of nutrients was indicated but those of the peat drainage and the lake effluents represented the higher level in winter and lower in summer. Anoxic conditions in the water column enhancing sulfate reduction are negligible and rarely observed. The Agmon merit to the reclamation process was achieved.
\end{abstract}

\section{Keywords}

Hula, Agmon, Nitrogen, Phosphorus, Macrophytes

\section{Introduction}

Lake Agmon is a newly created shallow body of water located in the middle part of the Hula Valley. The Hula region is part on the northern section of the great Syrian-African Rift Valley. The location of the man-made Lake Agmon was selected due to its position of the lowest regional altitude [1]. The objectives of Lake Agmon creation were aimed at three achievements [2]: 1) nutrients removal from the Lake Kinneret external loads; 2) to 
produce an ecological component for eco-tourism within the multi-functioned system of the Hula Project; 3) as a principle component for the hydrological management and agricultural irrigation system for the entire valley [2]-[4]. Until late fifties of the previous century, the Hula Valley was covered by swamps and old Lake Hula [5]. From 1958, the entire land of the Hula Valley was converted to agricultural area but during the 1980's it was found that in $8 \%$ of this farmland soil was deteriorated and agricultural development became non-profitable [6]-[8]. That was the reason for implementation of a reclamation proposal the "Hula Project" and construction of Lake Agmon was a part of it [1] [2]. Immediately after filling water in Lake Agmon (presently: volume- $0.44 \times$ $10^{6} \mathrm{~m}^{3}$; surface area-110 ha, average depth-0.4 m), it was a subject for monitoring and research aimed at evaluating an optimal model of operation. Optimized model of the management of Lake Agmon took into account the following objectives: improvement of irrigation water supply, maintenance of high underground water table ensuring peat soil moisture to prevent its deterioration, and the achievement of a high diversity of re-establishment of natural flora and fauna emphasizing aquatic birds and their nesting activity [2]. This paper is focused on two major issues: nutrient dynamics and the role of biomass and N \& P content of macrophytic vegetation within the lake ecosystem [4].

\section{Methods}

The water chemistry, the seasonal distribution of biomass and N \& P content of macrophytic plants were routinely monitored on weekly, bi-weekly and monthly basis during 1994-2014 and the discharge of major water sources as well. Sampling frequencies and station locations as well as the analytical methods are given in [9], and [10]. The method of aquatic plant monitoring is given in [11]. NTU was measured by standard Nephelometric method (Turbidity Meter HATCH Radio XR) and conversion of NTU values (used in this paper) to substance concentration (ppm) was experimentally defined as $1 \mathrm{NTU}=1.62 \mathrm{ppm}$ or $1 \mathrm{ppm}=0.86 \mathrm{NTU}$. In this paper the focus is given to three water sources in the Hula Valley [12]: 1) The reconstructed Jordan which supply about 50\% of the Agmon water budget; 2) The Canal Z which convey peat soil drainage waters into Lake Agmon contributing approximately 50\% of its capacity; and 3) the Lake Agmon outflow. For the presentation of nutrients mass balance in Lake Agmon the year 2005 was selected. Contribution of peat drainage waters not only through Canal Z but also from an eastern soil block was included but was found to be negligible.

\section{Results}

The relations between nutrient concentrations in the three sources (Canal Z, Reconstructed Jordan and Agmon Outflow) are presented in Table 1 and Figures 1-3. These figures were plotted as nutrient couples evaluations where the independent variable ( $\mathrm{X}$ axis) in ascent order and the predicted dependent variable (Y axis) respectively using Fractional Polynomial Method. Results in Table 1 represent significance level of the direct proportion relation level between NTU \& TP, NTU \& TP, and $\mathrm{SO}_{4}$ \& TDS in peat drained waters conveyed through Canal Z and in the Agmon effluents. The relations between NTU and TP are inversely related but insignificant. Figure 1 and Figure 2 show the direct proportional relations between these nutrients.

The origin of $\mathrm{P}$ in Canal $\mathrm{Z}$ is probably due mostly to geochemical processes and not erosive trait and therefore P concentration is not correlate with NTU level. It is suggested that the load of P in the waters of the Reconstructed Jordan and Agmon outflow is latent mostly within suspended particles: clay particles originate from erosion activity in the Jordan waters and plant debris in the Agmon outflow. Inverse relations were indicated between TN and TP in Canal Z waters which is in consent with the documented seasonal changes (Figures 1-5). Low $\mathrm{P}$ and high $\mathrm{N}$ in winter and vice versa in summer [12]. In the three water sources direct proportions were indicated between sulfate and TDS concentrations as a result of $\mathrm{SO}_{4}$ being the principle component which is accompanied by carbonates. Along the flow route of the Reconstructed Jordan waters, the dominant process affecting concentration changes of nutrients is probably particle sedimentation but not of chemical trait resulted in high stability of nutrient relations. The consistent relations between nitrogen forms conclusively justify an indication that nitrogen originate from one source, the peat soil.

Tables 2-4: Comparative analysis (ANOVA; p < 0.05) between winter months $(1-5)$ and summer months (6 - 12) of nutrient concentrations (ppm: $\mathrm{SO}_{4}$, TDS, NTU, $\mathrm{NH}_{4}, \mathrm{NO}_{3}, \mathrm{TN}, \mathrm{TDN}$; ppb: TP and TDP; EC in mS) in three sources: Agmon outflow, Canal Z, and Reconstructed Jordan. Data are monthly means (1994-2005). ${ }^{*} \mathrm{~S}=$ significant; NS = not significant. 
Table 1. Fractional polynomial regressions ( $\mathrm{r}^{2}$ and $\mathrm{p}$ values for the acceptance of the predicted variable) between monthly averages (1994-2005) of nutrient concentrations in Reconstructed Jordan, Canal Z, and Agmon outlet. NTU and TP; NH and $\mathrm{NO}_{3}$; TP and TN; $\mathrm{SO}_{4}=$ sulfate and TDS; $\mathrm{S}=$ significant; $\mathrm{NS}=$ not significant, (see also Figures 1-3).

\begin{tabular}{ccccc}
\hline Source & Nutrients compared & $\mathrm{r}^{2}$ & $\mathrm{p}$ & Significance \\
\hline Canal Z & $\mathrm{NTU} / \mathrm{TP}$ & 0.525 & 0.0077 & $\mathrm{~S}$ \\
Canal Z & $\mathrm{NH}_{4} / \mathrm{NO}_{3}$ & 0.748 & 0.0003 & $\mathrm{~S}$ \\
Canal Z & $\mathrm{TP} / \mathrm{TN}$ & 0.157 & 0.2029 & $\mathrm{NS}$ \\
Canal Z & $\mathrm{SO}_{4} / \mathrm{TDS}$ & 0.564 & 0.0049 & $\mathrm{~S}$ \\
Agmon outlet & $\mathrm{NTU} / \mathrm{TP}$ & 0.328 & 0.0417 & $\mathrm{~S}$ \\
Agmon outlet & $\mathrm{NH}_{4} / \mathrm{NO}_{3}$ & 0.702 & 0.0007 & $\mathrm{NS}$ \\
Agmon outlet & $\mathrm{TP}_{\mathrm{TN}}$ & 0.156 & 0.2036 & $\mathrm{~S}$ \\
Agmon outlet & $\mathrm{SO}_{4} / \mathrm{TDS}$ & 0.706 & 0.0006 & $\mathrm{~S}$ \\
Jordan & $\mathrm{NTU} / \mathrm{TP}$ & 0.427 & 0.0212 & $\mathrm{~S}$ \\
Jordan & $\mathrm{NH}_{4} / \mathrm{NO}{ }_{3}$ & 0.318 & 0.0500 & $\mathrm{~S}$ \\
Jordan & $\mathrm{TP} / \mathrm{TN}$ & 0.378 & 0.0334 & $\mathrm{~S}$ \\
Jordan & $\mathrm{SO}_{4} / \mathrm{TDS}$ & 0.564 & 0.0045 & \\
\hline
\end{tabular}

Table 2. Reconstructed Jordan.

\begin{tabular}{cccc}
\hline Parameter & Winter mean & Summer mean & ${\text { Probability }(\mathrm{p})^{*}}^{*}$ \\
$\mathrm{SO}_{4}$ & 42 & 25 & 0.1541 NS \\
$\mathrm{TDS}$ & 279 & 262 & 0.5633 NS \\
$\mathrm{NTU}$ & 8.7 & 9.8 & $0.6628 \mathrm{NS}$ \\
$\mathrm{NH}_{4}$ & 0.135 & 0.184 & $0.6809 \mathrm{NS}$ \\
$\mathrm{NO}_{3}$ & 1.3 & 1.4 & $0.9573 \mathrm{NS}$ \\
$\mathrm{TN}$ & 3.0 & 2.3 & $0.3124 \mathrm{NS}$ \\
$\mathrm{TDN}$ & 2.6 & 1.9 & $0.2058 \mathrm{NS}$ \\
$\mathrm{TP}$ & 102 & 122 & $0.2718 \mathrm{NS}$ \\
$\mathrm{TDP}$ & 46 & 63 & $0.2018 \mathrm{NS}$ \\
$\mathrm{EC}$ & 0.478 & 0.423 & $0.1143 \mathrm{NS}$ \\
\hline
\end{tabular}

Table 3. Canal Z.

\begin{tabular}{cccc}
\hline Parameter & Winter mean & Summer mean & ${\text { Probability }(\mathrm{p})^{*}}^{*}$ \\
$\mathrm{SO}_{4}$ & 875 & 351 & $0.0293 \mathrm{~S}$ \\
$\mathrm{TDS}$ & 1877 & 845 & $0.0147 \mathrm{~S}$ \\
$\mathrm{NTU}$ & 30 & 16 & $0.1427 \mathrm{NS}$ \\
$\mathrm{NH}_{4}$ & 10 & 2.7 & $0.0984 \mathrm{NS}$ \\
$\mathrm{NO}_{3}$ & 19.2 & 4.3 & $0.0071 \mathrm{~S}$ \\
$\mathrm{TN}$ & 30.1 & 6 & $0.0050 \mathrm{~S}$ \\
$\mathrm{TDN}$ & 26.6 & 5.3 & $0.0043 \mathrm{~S}$ \\
$\mathrm{TP}$ & 106 & 114 & $0.6286 \mathrm{NS}$ \\
$\mathrm{TDP}$ & 37 & 48 & $0.1678 \mathrm{NS}$ \\
$\mathrm{EC}$ & 2 & 1 & $0.0087 \mathrm{~S}$ \\
\hline
\end{tabular}



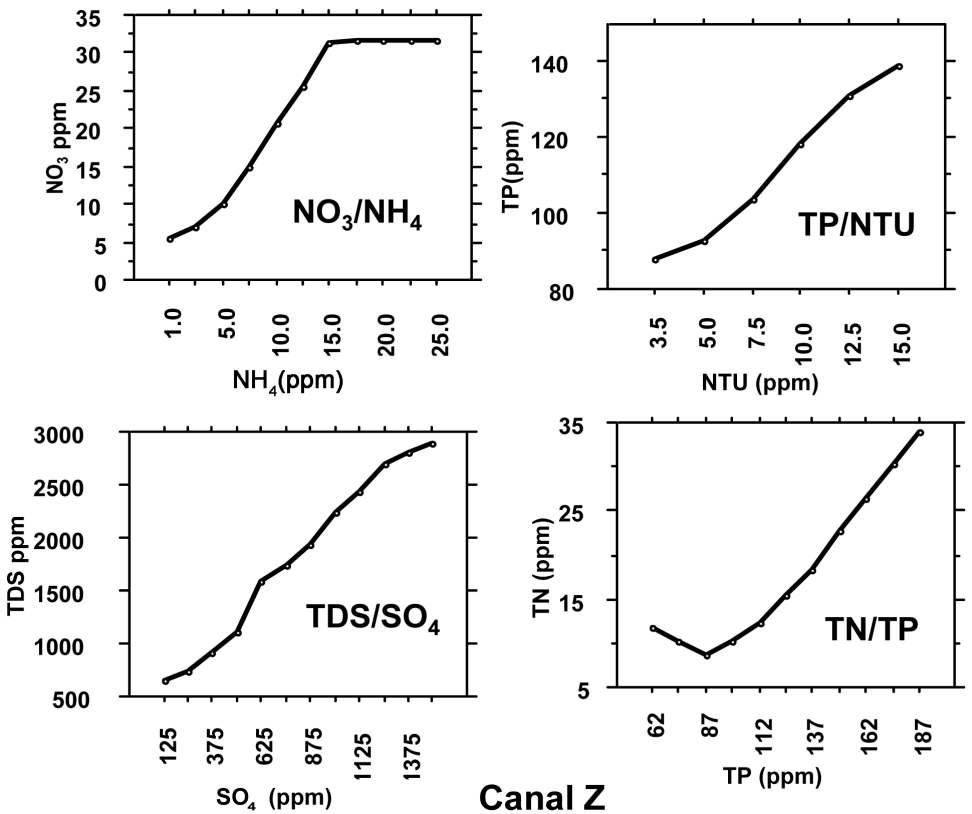

Figure 1. Canal Z: Fractional polynomial regression between $\mathrm{NH}_{4}$ and $\mathrm{NO}_{3}$ (top left), NTU and TP (top right), $\mathrm{SO}_{4}$ and TDS (bottom left) and TP and TN (bottom right).

Table 4. Agmon outflow.

\begin{tabular}{cccc}
\hline Parameter & Winter mean & Summer mean & ${\text { Probability }(\mathrm{p})^{*}}^{*}$ \\
$\mathrm{SO}_{4}$ & 727 & 497 & $0.0041 \mathrm{~S}$ \\
$\mathrm{TDS}$ & 1565 & 1000 & $<0.0001 \mathrm{~S}$ \\
$\mathrm{NTU}$ & 14.5 & 18.2 & $0.3433 \mathrm{NS}$ \\
$\mathrm{NH}_{4}$ & 2.0 & 0.5 & $0.1621 \mathrm{NS}$ \\
$\mathrm{NO}_{3}$ & 7.2 & 1.0 & $0.0048 \mathrm{~S}$ \\
$\mathrm{TN}$ & 9.1 & 2.5 & $0.0014 \mathrm{~S}$ \\
$\mathrm{TDN}$ & 7.6 & 1.6 & $0.0012 \mathrm{~S}$ \\
$\mathrm{TP}$ & 123 & 171 & $0.0321 \mathrm{~S}$ \\
$\mathrm{TDP}$ & 38 & 60 & $0.1732 \mathrm{NS}$ \\
$\mathrm{EC}$ & 1.8 & 1.0 & $<0.0001 \mathrm{~S}$ \\
\hline
\end{tabular}

Results indicate that the differences between summer and winter are not significant in the waters of Reconstructed Jordan.

The summer decline of nitrogen, sulfate and TDS and elevation of Phosphorus in Canal Z source are prominently shown in Table 4 [12].

Results given in Table 4 prominently indicates summer increase of NTU and Phosphorus (TP and TDP) concentrations which are the results of the degradation of submerged plants in the Lake [13]-[16]. On the other hand the summer concentrations of nitrogen forms significantly decline. The summer decline of Sulfate and TDS concentrations and obviously EC values are due to the discharge decline of peat drained waters into the Agmon through Canal Z.

Results given in Table 5 are emphasizing the annual concentrations decline of all nutrients except summer increase of Phosphorus (TP, TDP) in three sources: 

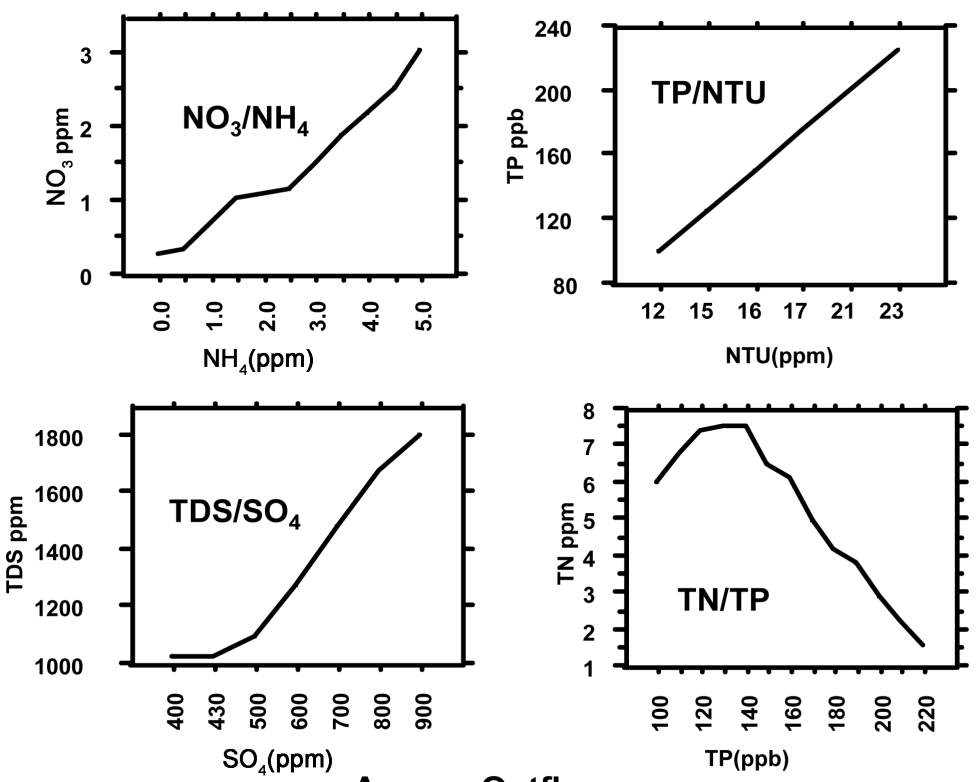

Agmon Outflow

Figure 2. Lake Agmon Outflow: Fractional polynomial regression between $\mathrm{NH}_{4}$ and $\mathrm{NO}_{3}$ (top left), $\mathrm{NTU}$ and TP (top right), $\mathrm{SO}_{4}$ and TDS (bottom left) and TP and TN (bottom right).
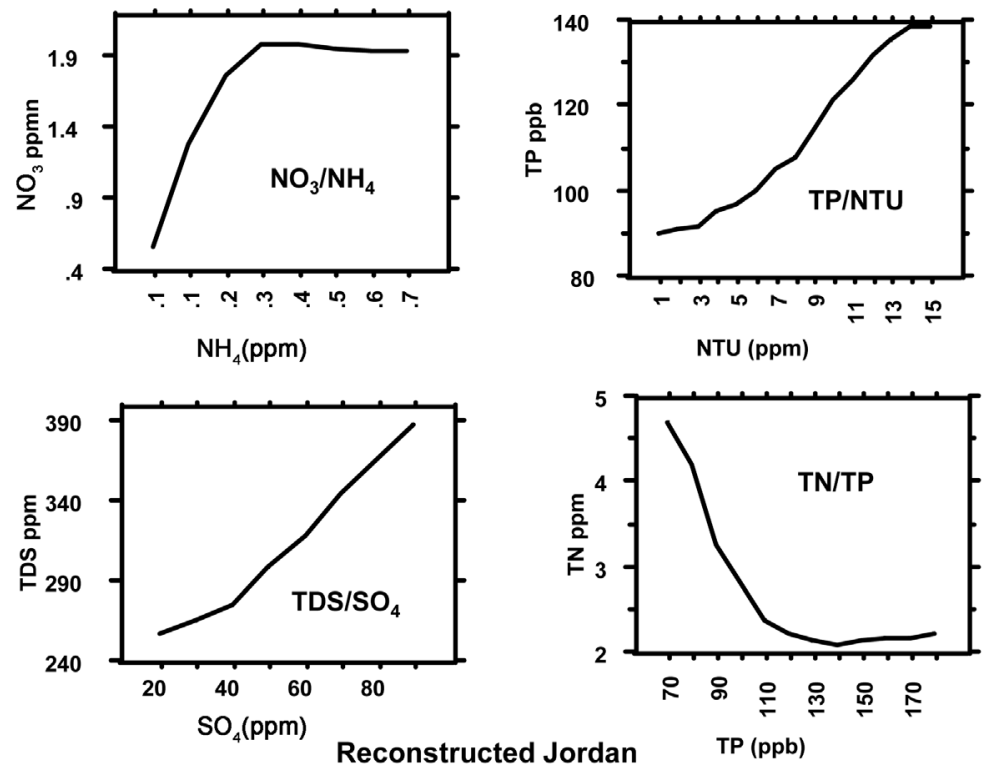

Figure 3. Reconstructed Jordan: Fractional polynomial regression between $\mathrm{NH}_{4}$ and $\mathrm{NO}_{3}$ (top left), $\mathrm{NTU}$ and TP (top right), $\mathrm{SO}_{4}$ and TDS (bottom left) and TP and TN (bottom right).

Insignificant in Reconstructed Jordan and all others-significant (see also Figure 4 and Figure 5).

Results in Table 6 indicate that the TN, TP, Sulfate and Alkalinity loads from Hula East (eastern peat block separately drained) comprised only 5\%, 7\%, 13\%, 6\% of the total peat drainage (Canal Z + Hula East) loads of TN, TP, Sulfate and Alkalinity respectively. For the calculation of nutrient mass balances the information about water budget is needed combined with the chemical data. It has to be considered that precise data of Water Budget was available for the years of 2005 and 2006 and 2005 was selected. The reason for that is the introduction of an automatic system of flow meters and calibrations were not yet completed. 

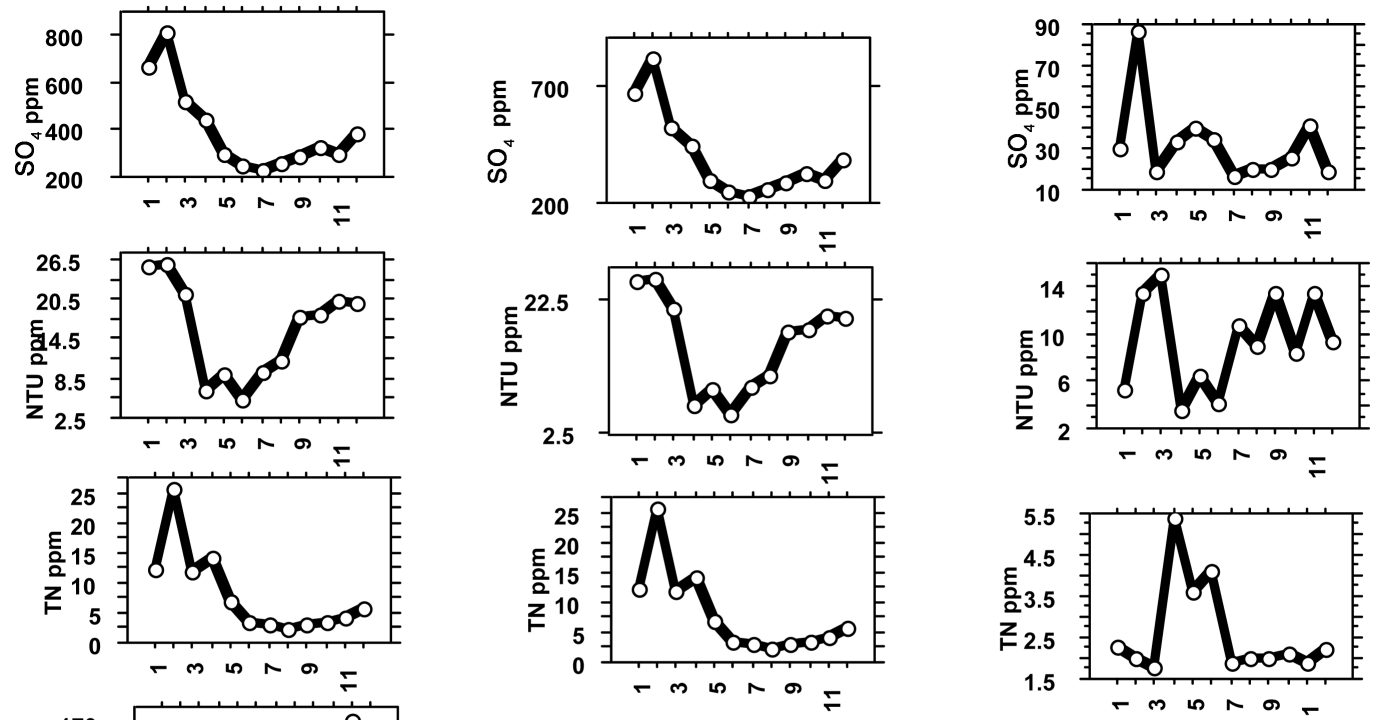

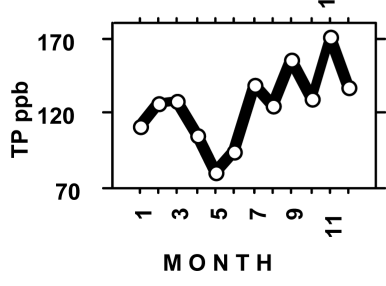

Agmon Outflow

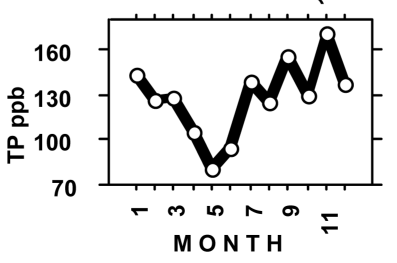

Canal Z

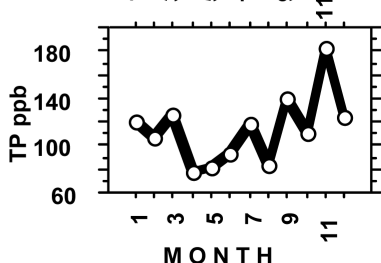

Jordan

Figure 4. Monthly averages (1994-2005) of nutrient concentrations: $\mathrm{SO}_{4}, \mathrm{NTU}$, TN, in ppb and TP in ppb, in Agmon Outflow, Canal Z, Reconstructed Jordan.

Table 5. Linear regression of monthly (January to December) means of nutrient concentrations (ppm: $\mathrm{SO}_{4}, \mathrm{TDS}, \mathrm{NTU} \mathrm{NH}_{4}$, $\mathrm{NO}_{3}$, TN, TDN, TP and TDP; EC in mS) as averaged for the entire period of 1994-2005 in the three sources: Canal Z (CZ), Reconstructed Jordan (RJ), and Agmon outflow (AO). The annual trend of change ( $\mathrm{D}=$ decrease, $\mathrm{I}=$ increase) and significance level $(\mathrm{S}=$ significant $<0.05$; NS = not significant $>0.05)$ are indicated.

\begin{tabular}{|c|c|c|c|c|c|c|}
\hline Nutrient & $r^{2} R J$ & $\mathrm{r}^{2} \mathrm{CZ}$ & $\mathrm{r}^{2} \mathrm{AO}$ & Trend RJ & Trend CZ & Trend AO \\
\hline $\mathrm{SO}_{4}$ & 0.1699 & 0.3071 & 0.5596 & NS I & S D & S D \\
\hline TDS & 0.0655 & 0.3724 & 0.7392 & NS I & S D & S D \\
\hline NTU & 0.0408 & 0.3735 & 0.2271 & NS D & S D & NS D \\
\hline $\mathrm{NH}_{4}$ & 0.0461 & 0.1348 & 0.2177 & NS D & NS D & NS I \\
\hline $\mathrm{NO}_{3}$ & 0.0041 & 0.1630 & 0.4787 & NS I & NS D & S D \\
\hline $\mathrm{NO}_{2}$ & 0.0025 & 0.2675 & 0.2235 & NS I & NS D & NS D \\
\hline $\mathrm{TN}$ & 0.0699 & 0.1569 & 0.4772 & NS I & S D & S D \\
\hline TDN & 0.0899 & 0.1596 & 0.5317 & NS I & S D & S D \\
\hline $\mathrm{TP}$ & 0.1732 & 0.7490 & 0.5105 & NS D & S I & S I \\
\hline TDP & 0.2234 & 0.8310 & 0.2368 & NS D & NS I & NS I \\
\hline EC & 0.1494 & 0.4309 & 0.6254 & NS I & NS D & S D \\
\hline
\end{tabular}

The low levels of sulfate, TDS, NTU, nitrogen, and EC in Jordan waters which do not contain peat drainage effluents are prominently shown in Table 7. Higher levels of concentration of sulfate, TDS, NTU, and nitrogen in waters drainage from the eastern peat block of (Hula East) than those measured in Canal Z (Drained from the 

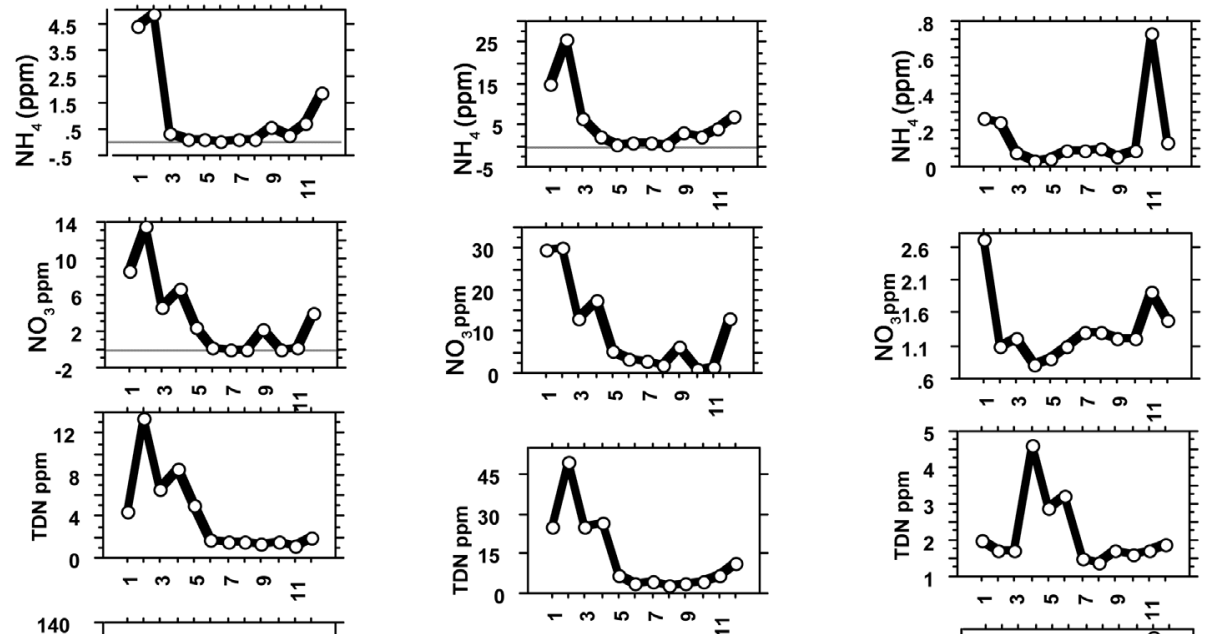

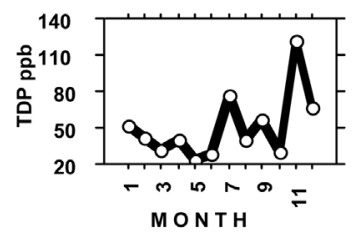

Agmon Outlflow

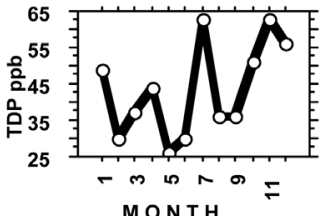

Canal Z

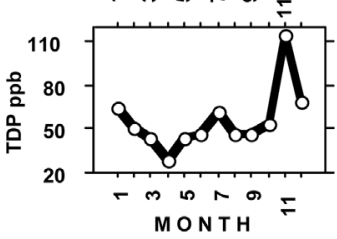

Jordan

Figure 5. Monthly averages (1994-2005) of nutrient concentrations: $\mathrm{NH}_{4}, \mathrm{NO}_{3}, \mathrm{TDN}$, in ppm and TDP in ppb in Agmon Outflow, Canal Z, Reconstructed Jordan.

Table 6. Total annual nutrient loads (tons/year) input into Lake Agmon through Reconstructed Jordan, Peat Drainage Canal Z \& Hula East) and Lake Agmon outflow during 2005: $\mathrm{CO}_{3}=$ alkalinity.

\begin{tabular}{ccccccccccc}
\hline Source/nutrient & $\mathrm{TN}$ & $\mathrm{TDN}$ & $\mathrm{TP}$ & $\mathrm{TDP}$ & $\mathrm{NO}_{3}$ & $\mathrm{NH}_{4}$ & $\mathrm{SO}_{4}$ & $\mathrm{TDS}$ & $\mathrm{CO}_{3}$ \\
\hline Reconstructed Jordan & 5.6 & 4.7 & 0.2 & 0.1 & 4.4 & 0.01 & 39 & 70 & 440 \\
Canal Z & 31.0 & 28.8 & 0.5 & 0.1 & 14.4 & 9.9 & 674 & 149 & 915 \\
Hula East & 1.5 & 1.2 & 0.03 & 0.01 & 0.6 & 0.2 & 104 & 6 & 54 \\
Agmon Outflow & 27.3 & 21.6 & 1.2 & 0.2 & 3.3 & 7.2 & 956 & 243 & 577 \\
\hline
\end{tabular}

Table 7. Totally averaged concentrations (1994-2005) of nutrients (ppm), pH (pH units), EC (mS), NTU (converted to ppm) in Reconstructed Jordan, Peat Drainage (Canal Z), and Agmon Outflow.

\begin{tabular}{ccccc}
\hline Nutrient/source & Reconstructed Jordan & Canal Z & Agmon outflow & Hula East \\
\hline $\mathrm{SO}_{4}$ & 32 & 569 & 631 & 879 \\
$\mathrm{TDS}$ & 269 & 1275 & 1301 & 2273 \\
$\mathrm{NTU}$ & 9 & 21 & 17 & 34 \\
$\mathrm{NH}_{4}$ & 0.2 & 5.7 & 1.3 & 2 \\
$\mathrm{NO}_{3}$ & 1.4 & 10.5 & 4.3 & 6.6 \\
$\mathrm{NO}_{2}$ & 0.03 & 0.3 & 0.3 & 0.1 \\
$\mathrm{TN}$ & 2.6 & 16 & 6.0 & 9.3 \\
$\mathrm{TDN}$ & 2.2 & 14.2 & 4.8 & 8.4 \\
$\mathrm{TP}$ & 0.11 & 0.11 & 0.15 & 0.2 \\
$\mathrm{TDP}$ & 0.06 & 0.04 & 0.05 & 0.1 \\
$\mathrm{EC}$ & 0.4 & 1.4 & 1.4 & 1.7 \\
$\mathrm{pH}$ & 7.8 & 7.4 & 7.9 & 7.5 \\
\hline
\end{tabular}


middle valley peat block) are also indicated. Due to the minor discharges from the eastern block (Hula East) the loads are negligible.

\section{Submerged and Emerged Macrophytes [4] [10]}

The study of the submerged and emerged vegetation recorded 10 species of high plants and filamentous algae. Submerge: Potamogeton spp. Ceratophyllum, and Najas spp. Emerge: Phragmites sp., Typha sp. The total biomass (dw) and the content of phosphorus and nitrogen in plant matter was monthly monitored and the results are summarized in Table 8. The initiation of the aquatic vegetation onset occur usually in April, peaked in JulyAugust than offset begin until dieback disappearance in December. Between December and next April the biomass is negligible.

Results given in Table 4 and Table 8 conclusively indicates that the origin of most of the Phosphorus in the Agmon outflow (1.2 t) is plant mediated and approximately 50\% of the nitrogen output as well [16]-[19].

\section{Discussion}

There are two different types of bottom sediments in Lake Agmon: The northern part which is comprised of organic peaty matter and occupy $70 \%$ of the surface and the southern part (30\%) which is made of chalk-marl [3]. The difference is due to the land cover prior to the drainage. The northern landscape was swampy and the northern part old lake Hula covered the southern part of Lake Agmon. Therefore sediment composition in the northern part of Agmon contain mostly decomposed plant material and in the south sediments are mostly carbonates [3]. Not as in many other wetlands in the world, concentration of sulfate in Lake Agmon is high. The sulfate source is gypsum dissolution. The gypsum was formed in the peat organic soil after the Hula Valley drainage during 1952-1958. The major source of sulfate to Lake Agmon is soluble gypsum in the peat soil. The sulfate is transported to the lake by peat soil drainage waters and minority through advective flux through the bottom. The sulfate is the major merit to the water EC. The sulfate reduction to sulfide which react with ferrous iron and settled as FeS minerals was previously documented [3]. Nevertheless, the consequence of eliminating sulfides toxicity as the reason of plant mortality was predicted [20]-[24]. Dieback of wetlands vegetation is widely known and sulfide toxicity is relevant only if their concentration is much higher than that was measured in the uppermost layer of the Agmon sediments. The submerged macrophytes in Lake Agmon are shallow rooted and the root system of the emergent reeds is deeper. Consequently, nutrient availabilities are probably differ for the shallow and deep rooted vegetation. Immediately after filling Lake Agmon with water in summer 1994 a dense vegetation of Typha domingensis developed in the southern part of the lake on the chalk-marl bottom. The Typha dense stands entirely collapsed and disappeared during the second half of 1996 and partly re-appeared close to the southern shoreline three years later. The effect of Sulfide toxicity and N \& P limitations on the offset of Cyperus papyrus was tested [25]. Nitrogen and P limitations were confirmed but Sulfide toxicity was not [25].

Plant mortality resulted by Sulfide toxicity was not confirmed and P limitation as the reason for the dieback of Typha domingensis in Lake Agmon during 1995 was concluded [7]. The seasonal onset-offset growth cycle of

Table 8. Peaks of aquatic vegetation biomass (tons DW) in the entire lake and $\mathrm{P}$ and $\mathrm{N}$ total contents (tons) during 19972004.

\begin{tabular}{cccc}
\hline Year & Total biomass $t(d w)$ & Phosphorus (t) & Nitrogen (t) \\
1997 & 268 & 0.9 & 7.4 \\
1998 & 213 & 0.7 & 6.3 \\
1999 & 432 & 0.8 & 7.8 \\
2000 & 343 & 0.9 & 6.6 \\
2001 & 740 & 1.2 & 9.8 \\
2002 & 817 & 1.2 & 9.8 \\
2003 & 140 & 0.3 & 2.7 \\
2004 & 698 & 1.1 & 10.5 \\
\hline
\end{tabular}


submerged macrophytes other than Typha sp. in Lake Agmon is not related to nutrient limitation, neither P nor $\mathrm{N}$, due to their shallow rooted system. The upper 5 centimeters layer of the bottom sediments is under continuity of settled nutrients renewal which are available to the shallow rooted plants. The upper $5 \mathrm{~cm}$ of the bottom sediments over the entire lake contain 600 - 990 ppm (mg/Kg dry matter) whilst deeper layers content was varied between 350 - 585 ppm [7]. It is also possible that the chemical bounds of $\mathrm{P}$ to the sediment particles is not of the same type in deep $(>5 \mathrm{~cm})$ and shallow $(<5 \mathrm{~cm})$ layers. If the density of the bottom sediments averaged for the whole lake as $1.36 \mathrm{ton} / \mathrm{m}^{3}$ and water content (porosity) is $50 \%$ (data is not given here) and total surface area is $1100 \times 10^{3} \mathrm{~m}^{2}$ the P stock in the upper $5 \mathrm{~cm}$ of the bottom sediments is $22.4-37.0$ ton $\mathrm{P}$ and in the layer $5 \mathrm{~cm}$ below is 11.2 - 21.9 ton P. The P concentration in the marl bottom is lower than that in the northern organic sediments. Nevertheless, due to chemical differences, the availability of P in the "marl-chalk" sediments is higher than that in the organic peat sediment. Moreover the construction of Lake Agmon exposed the soil to oxygenation enhancing $\mathrm{P}$ availability which is optimal for Typha vegetation but the later water cover reduced $\mathrm{P}$ availability causing plants collapsing. It is likely that the limiting factor for the shallow rooted submerged macrophytic production in Lake Agmon is not element nutrition but probably thermal and partly light penetration as affected by water depth and clarity. During early stages (1994-1996) of Lake Agmon system, an intensive growth production of macrophyte was qualitatively monitored [4]. Later, (1997-2013) a quantitative documentation was initiated [9] [10]. The information about the $\mathrm{N}$ and $\mathrm{P}$ content of the submerged vegetation accompanied by the seasonal biomass onset-offset cycle of those plants conclusively justify to relate plant mediated $\mathrm{P}$ contribution to the Agmon chemical mass balance. The P cycled pathway is outlined as follows: external particulate $\mathrm{P}$ is influx into the lake from external sources, and then settled to the upper bottom layer sediments enriching the P stock there. This P stock is partly incorporated by submerged macrophytes which are later dieback, decompose and released P back to the water as particulate and dissolved forms [26]. The contribution of TDP to the Agmon water column via advection flows from bottom upward is probably negligible [3]. Three gram per $\mathrm{m}^{2}$ per year of plant (Myriophyllum spicatum) mediated P release from bottom sediments into the overlying water was documented [15]. If similar rate is applied to Lake Agmon it makes a total of 3.3 tons of P flux from the bed-sediments to the water column. The P uptake by submerged macrophytes occur through the roots [14] and leaves [27]. The pore waters in Lake Agmon are probably highly richer in $\mathrm{P}$ than the overlying waters and the rooted vegetation incorporate their $P$ demands from the interstitial sediments pore waters [14]. This $P$ is released to the water by the plant decay [26] [28]. The P-rich upper $5 \mathrm{~cm}$ sediment layer is a benefit for the shallow rooted submerged macrophytes. The development of emerged deep rooted plants as Typha, and partly Phragmites in water covered area is episodic because of $\mathrm{P}$ and probably $\mathrm{N}$ limitation in sediments depth below $5 \mathrm{~cm}$. Moreover, Typha is known by its high P-demands and P limitation in the deep layers probably create P insufficiency as for Cyperus papayrus for both $\mathrm{N}$ and $\mathrm{P}$ [25]. The contents of $\mathrm{P}$ and $\mathrm{N}$ in the peat soil is high. Nevertheless because $\mathrm{P}$ is bounbded to organic substances it can be released mostly under low level of moisture when those linkages are breakable. These conditions are common in summer. This is the reason for the high level of $\mathrm{P}$ concentrations in the peat drainage waters conveyed through Canal $\mathrm{Z}$ in summer [12]. The content of nitrogen compounds (mostly Nitrate) in peat soil is high too but their removal rate by water flushing in winter is high because of their weak adhesive to the peat soil particles. This is the reason for $\mathrm{N}$ concentration decline in summer in Canal $\mathrm{Z}$.

The nitrogen cycle in wetlands is dominated by de-nitrification [23]. Due to the high content of organic matter the reducing capacity is large. It was also documented [23] that denitrification can also be controlled by FeS. The FeS controlled de-nitrification is mediated by Sulfur cycle bacteria and stoicheiometric relation exists between nitrate reduced and sulfate produced and the bacteria also use nitrate for their nitrogen demands. The chemical mass balance of Lake Agmon indicates significant surplus outflow of sulfate accompanied by nitrogen retaining, possibly by de-nitrification. Lake Agmon is nitrogen rich in winter due to heavy floods input of nitrates through the Jordan and Canal $\mathrm{Z}$ inflows. The concentrations of all nitrogen forms in the Agmon outflow are lower than those measured in the inflows. The nitrogen removal is done within the Agmon waters by denitrification and sedimentation of particles originates mostly from biotic sources.

\section{Summary}

Conclusive summary of 20 years of research and monitoring of the Lake Agmon System in the Hula Valley (Israel) has indicated the followings: Lake Agmon is a nitrogen sink by de-nitrification and sedimentation whilst surplus phosphorus is contributed by seasonal onset and offset of submerged and emerged macrophytic vegeta- 
tion; concentrations of $\mathrm{P}$ in the system increase in summer when $\mathrm{N}$ is declining; nutrients composition in the reconstructed Jordan are stable as a result of low geochemical activities; $\mathrm{SO}_{4}$ and carbonates comprise most of the TDS fraction and EC is highly related to their concentration. NTU as converted into ppm units is highly related to P concentration; all nitrogen forms are simultaneously fluctuated.

\section{References}

[1] Gophen, M., Tsipris, Y., Meron, M. and Bar-Ilan, I. (2003) The Management of Lake Agmon Wetlands (Hula Valley, Israel), Shallow Lake Conference, Lake Balaton, Hungary, June 2002. Hydrobiologia, 506, 803-809. http://dx.doi.org/10.1023/B:HYDR.0000008602.77264.8c

[2] Gophen, M. (2004) Water Utilization in a Semi-Arid Zone, the Hula Valley (Israel): Pollutant Removal, Agriculture and Ecotourism Management. In: Zereini, F. and Hotzl, H., Eds., Water in the Middle East and in North Africa: Resources, Protection, and Management, Springer-Verlag, Berlin, 207-226. http://dx.doi.org/10.1007/978-3-662-10866-6_18

[3] Markel, D., Sass, E., Lazar, B. and Bein, A. (1998) Biochemical Evolution of a Sulfur-Iron Rich Aquatic System in a Reflooded Wetlands Environment (Lake Agmon, Northern Israel). Wetlands Ecology and Management, 6, 103-120. http://dx.doi.org/10.1023/A:1008407800060

[4] Kaplan, D., Oron, T. and Gutman, M. (1998) Development of Macrophytic Vegetation in the Agmon Wetland in Israel by Spontaneous Colonization and Reintroduction. Wetlands Ecology and Management, 6, 143-150. http://dx.doi.org/10.1023/A:1008420120533

[5] Dimentman, Ch., Bromley, H.J. and Por, F.D. (1992) Lake Hula Reconstruction of Fauna and Hydrobiology of Lost Lake. The Israeli Academy of Sciences and Humanities, Jerusalem, 170 p.

[6] Gophen, M. (2000) The Hula Project: N and P Dynamics in Lake Agmon and Pollutants Removal from the Kinneret Inputs. Water Science and Technology, 42, 117-122.

[7] Gophen, M. (2000) Nutrient and Plant Dynamics in Lake Agmon Wetlands (Hula Valley, Israel): A Review with Emphasis on Typha Domingensis (1994-1999). Hydrobiologia, 441, 25-36. http://dx.doi.org/10.1023/A:1017525804657

[8] Paine, R. and Gophen, M. (22011/2012) Mires and Peat, the Hula Peatland: Past, Present and Future. Volume 9 Special Volume. Compiled by Richard Paine with Guest Editor Moshe Gophen: Forward by R/Paine and M. Gophen.

[9] Gophen M. (Ed.) (1995-2006) Hula Project Annual Reports; Migal, Water Authority, and Jewish National Fund (KKL), (in Hebrew).

[10] Barnea, I. (Ed.) (2007-2013) Hula Project Annual Reports; Migal, Water Authority, and Jewish National Fund (KKL), (in Hebrew).

[11] Kaplan, D. and Niv, T. (1997-2005) Chapters of Submerged and Emerged Vegetation. In: Gophen, M., Ed., Annual Reports of Hula Projects.

[12] Gophen, M., Meron, M., Orlov-Levin, V. and Tsipris, Y. (2014) Seasonal and Spatial Distribution of N \& P Substances in the Hula Valley (Israel) Subterranean. Open Journal of Modern Hydrology, 4, 121-131. http://dx.doi.org/10.4236/ojmh.2014.44012

[13] Carpenter, S.R. (1980) Enrichment of Lake Wingra, Wisconsin, by Submerged Macrophytes Decay. Ecology, 61, 1145-1155. http://dx.doi.org/10.2307/1936834

[14] Carignan, R. and Kalf, J. (1982) Phosphorus Release by Submerged Macrophytes: Significance to Epiphyhton and Phytoplankton. Limnology and Oceanography, 27, 419-427. http://dx.doi.org/10.4319/lo.1982.27.3.0419

[15] Smith, C.S. and Adams, M.S. (1986) Phosphorus Transfer from Sediments by Myriophyllum spicatum. Limnology and Oceanography, 31, 1312-1321.

[16] Nichols, D.S. and Kenney, R. (1973) Nitrogen and Phosphorus Release from Decaying Water Milfoil. Hydrobiologia, 42, 509-525. http://dx.doi.org/10.1007/BF00047023

[17] Davis, S.M. (1997) Phosphorus Inputs and Vegetation Sensitivity in the Everglades. In: Davis, S.M. and Ogden, J.C., Eds., Everglades the Ecosystem and Its Restoration, Lucie Press, Delray Beach, 357-378.

[18] Davis, S.M., Gunderson, L.H., Park, W.A., Richardson, J.R. and Mattson, J.E. (1997) Landscape Dimension, Composition, and Function in a Changing Everglades Ecosystem. In: Davis, S.M. and Ogden, J.C., Eds., Everglades the Ecosystem and Its Restoration, Lucie Press, Delray Beach, 419-444.

[19] Peverly, J.H. and Brittain, J. (1978) Effect of Milfoil (Myriophyllum spicatum L.) on Phosphorus Movement between Sediments and Water. Journal of Great Lakes Research, 4, 62-68. http://dx.doi.org/10.1016/S0380-1330(78)72166-0

[20] Reddy, R.K. and D’Angelo, E.M. (1994) Soil Processes Regulating Water Quality in Wetlands. In: Mitch, W.J., Ed., Global Wetlands Old World and New, Elsevier, Amsterdam, 309-324. 
[21] Smolders, A. and Roelofs, J.G.M. (1993) Sulfate Mediated Iron Limitation and Eutrophication in Aquatic Ecosystems. Aquatic Botany, 46, 247-253. http://dx.doi.org/10.1016/0304-3770(93)90005-H

[22] Richardson, J.C. (1990) Biogeochemical Cycles: Regional. In: Patten, B.C., Ed., Wetlands and Shallow Continental Water Bodies, SPB Academic Publishing, The Hague, 259-280.

[23] Golterman, H.L. (1995) The Labyrinth of Nutrient Cycles and Buffers in Wetlands: Result Based on Research in the Camargue (Southern France). Hydrobiologia, 315, 39-58. http://dx.doi.org/10.1007/BF00028629

[24] Van Wijck, C., de Groot, C.-J. and Grillas, P. (1992) The Effect of Anaerobic Sediment on the Growth of Potamogeton pectinatus L.: The Role of Organic Matter, Sulphide and Ferrous Iron. Aquatic Botany, 44, 31-49. http://dx.doi.org/10.1016/0304-3770(92)90079-X

[25] Simhayov, R., Iggy Litaor, M., Barnea, I. and Shenker, M. (2013) Catastrophic Dieback of Cyperus papyrus in Response to Geochemical Changes in an East Mediterranean Altered Wetland. Wetlands, 33, 747-758. http://dx.doi.org/10.1007/s13157-013-0434-9

[26] Barko, J.W. and Smart, R.M. (1980) Mobilization of Sediment Phosphorus by Submerged Freshwater Macrophytes. Freshwater Biology, 10, 229-238. http://dx.doi.org/10.1111/j.1365-2427.1980.tb01198.x

[27] McRoy, C.P., Barsdate, R.J. and Nebert, M. (1972) Phosphorus Cycling in an Eelgrass (Zostera marina L.) Ecosystem. Limnology and Oceanography, 17, 58-67. http://dx.doi.org/10.4319/lo.1972.17.1.0058

[28] Horn, J.A. and Goldman, C.R. (1994) Phosphorus Cycling in the Water Column. In: Limnology, McGraw-Hill Inc., New York, 163-164. 